総 説 (Review Article): 膜 (MEMBRANE), 21 (5), 276-282 (1996)

๑特集 : 気体・蒸気分離膜の実用化の現状と展望

\title{
炭酸ガス・水素ガス分離膜と装置
}

\author{
楠 木 喜 博
}

宇部興産(株) 高分子研究所 可 290 市原市五井南海岸 8-1

\section{Preparation and Application of Carbon Dioxide Separation Membrane and Hydrogen Separation Membrane}

\author{
Yoshihiro Kusuki \\ Polymer Labratory, UBE Industries, LTD. \\ 8-1 Goi-Minamikaigan Ichihara Chiba 290, Japan
}

The new polyimide hollow fiber membranes for carbon dioxide separation and hydrogen separation membrane were developed.

These membranes are applied to oil refeinry, chemical process, natural gas treatment and landfill gas upgrading.

Key words : membrane/hydrogen separation/carbon dioxide separation

\section{1.はじめに}

ガス分離分野において最初に実用化された膜は 水素分離膜であった. これをきっかけにして数多 くの膜材料が開発され，そのうちいくつかが実用 化された.

芳香族ポリイミドは現存する有機高分子の中で 最も耐熱性に優れ, さらに優れた耐溶剤性, 機械 的性質, ガスの高分離性を有している.このこと は，おうおうにして加工性の低下を伴うのが常で あった. 当社が開発した BPDA ベースのポリイ ミドはポリイミドの優れた特性に加え，1)フェ ノール系溶剤に可溶である，2) 紡糸性に優れて (る，3) 非対称性膜の成形が容易である等の特
長を有していた (Table 1). この性質は, ガス分 離膜素材として好ましい特性である.

水素分離膜あるいは炭酸ガス分離膜は, 処理量 も比較的大量で, 分離性能と共に耐圧性, 而溶剂 性などの性能も要求される.

本稿ではポリイミド膜の開発と特長, 水素分離, 炭酸ガス分離に対する要求特性, およびその特長 が活かされている実用例について紹介する.

\section{2. ポリイミド膜の製造技術}

分離膜のガスの透過速度を大きくすることは膜 の設計・製造の上で最も重要な技術開発の 1 つで ある. すなわち透過係数の大きい素材の探索と薄 
膜化技術の開発がその対象となる. 一般の無機ガ スおよび低分子の炭化水素ガス（メタン, エタン 等）の透過速度の差は膜中の拡散速度の差による ところが大きい. 我々は ${ }^{1)}$ ガラス状高分子中のガ ス拡散が高分子の運動性および凝集エネルギー密 度 (CED) と相関のあることを見出した.このこ とにより，ポリマーの CED を計算することによ り特定のガスのポリマー中の透過速度のおおよそ の值が予想でき，分子設計上有用となった.

膜形状としては中空糸, チューブラー, および

Table 1 Structure and characteristics of UBE's polyimide

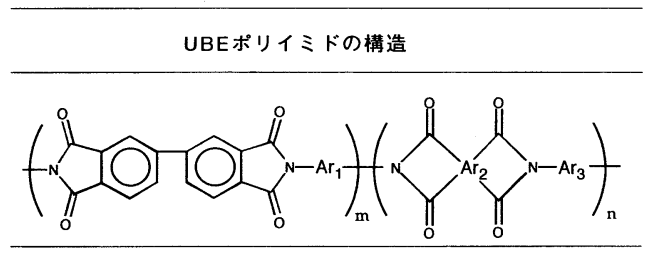

UBEポリイミドの特長

1）特殊な溶媒に可溶である（ハロゲン化フェノール）

2）紡糸性が良好である

3）非対称性膜の製造が容易である
平膜タイプが挙げられる. Table 2 に各膜を圧力 容器に充填したときの単位体積当たりの膜面積を 示す ${ }^{2)}$. ガス分離膜の場合, 水処理膜と異なり, 膜面でのファウリングや濃度分極を考慮する必要 がほとんどなく, 最近では, 平膜よりはむしろ単 位体積当たりの膜面積の大きい中空糸が多く採用 されている. 実用化膜はガスの透過速度を大きく するために分離に寄与する緻密層をできるだけ薄 くする工夫が成されている. 当社のポリイミドガ ス分離膜はロエブ・スーリラジャンが開発した乾 湿式法に準じて製造されている．Fig. 1にガス分

Table 2 Area/Volume utilization for follow fiber and flat membrane

\begin{tabular}{|c|c|}
\hline 膜形態 & 膜面積 $\left(\mathrm{ft}^{2} / \mathrm{ft}^{3}\right)$ \\
\hline \multicolumn{2}{|l|}{ 中空糸 } \\
\hline 外径 : & 12,000 \\
\hline 100 & 6,000 \\
\hline 200 & 3,000 \\
\hline 300 & 2,000 \\
\hline 平膜, スパイラル & $150 \sim 200$ \\
\hline \multicolumn{2}{|l|}{ チューブラー } \\
\hline 外径 : 0.5 inch & 50 \\
\hline
\end{tabular}
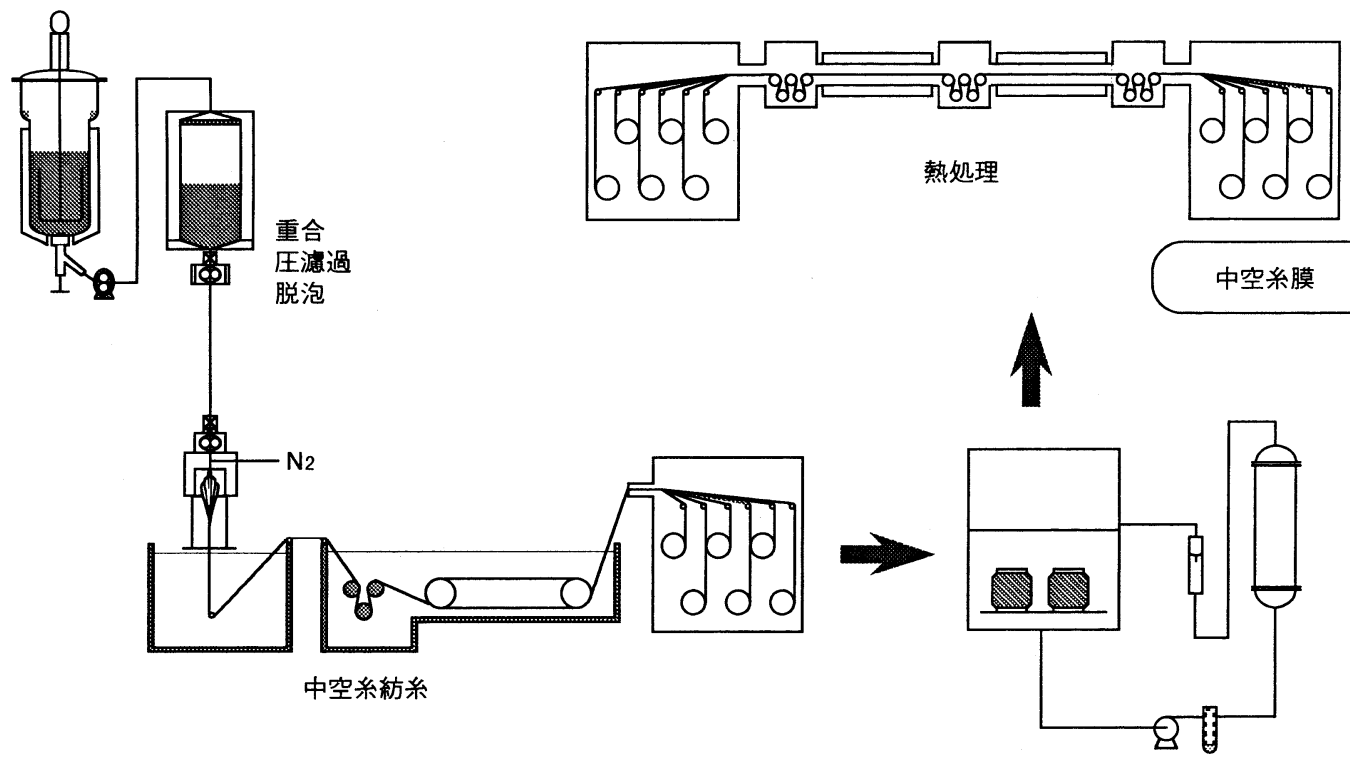

洗浄、乾燥

Fig. 1 Manufacturing process of polyimide hollow fiber membrane 


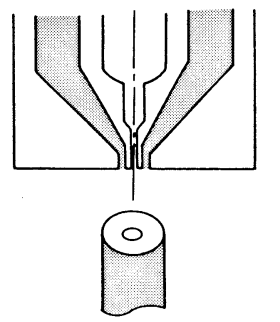

a. 単層ノズル

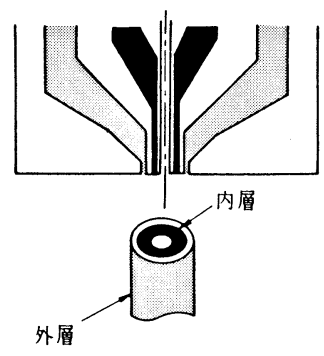

b. 複層ノズル

Fig. 2 Preparation of Double layer asymmetric hollow fiber membrane

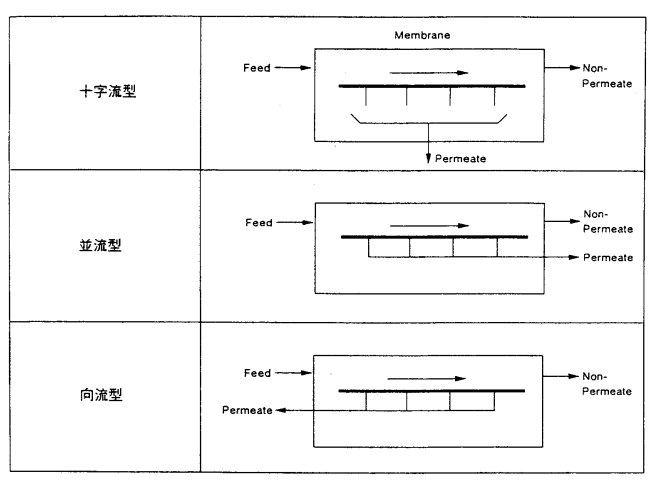

Fig. 4 Mode of flow pattern

離用ポリイミド中空糸膜の製造フローを示す。こ のようにして外径 300〜600 $\mu \mathrm{m}$ 膜厚 60〜150 $\mu \mathrm{m}$ の中空糸が作られる.

我々は ${ }^{3)}$, 高圧条件下で高透過, 高分離特性を 示すポリイミド中空糸膜の製造法として複層紡系 技術を開発した. Fig. 2 に複層紡糸技術の概念を 示す.二層スリット構造ノズルの外層から透過性, 分離性に優れたポリイミドの紡糸溶液を, 内層か ら機械的物性に優れたポリイミドの溶液を吐出し て中空糸膜の製造を行うものである. Fig. 3 に複 層膜破断面の SEM 写真を示す。この複層紡糸法 により透過性, 分離性に優れた膜素材の特長を保 持したまま，耐圧性にも優れた分離膜の製造が可 能になった。

\section{3. モジュール化工程}

ガス分離膜は，前にも述べたとおり，膜面での

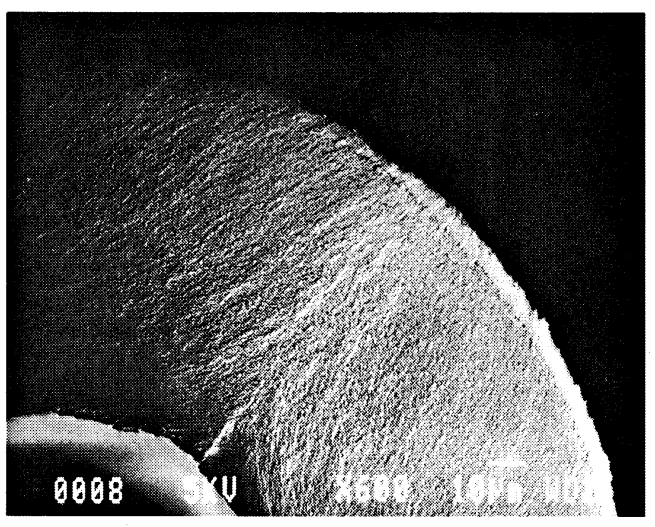

Fig. 3 Cross section of Double layer hollow fiber membrane

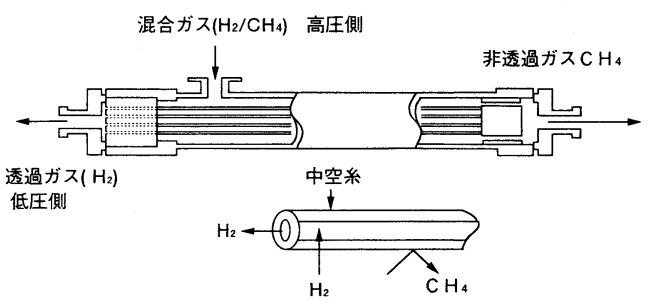

Fig. 5 Hollow fiber membrane module (High pressure type)

ファウリングや濃度分極を考慮する必要がないた め, プレフィルターなどの装置により膜表面の污 染を防止する工夫をすれば，膜の性能に応じた分 離が可能となる. しかし，モジュールとして高性 能を発揮するためには，ガスの流れ方，ショート パスの防止，膜の耐圧強度など，その他多くの因 子を考慮したモジュールの設計が必要であり， 数々の工夫が成されている. 実用モジュールに想 定されるガス流れの形式はおよそ 3 通りが考えら れる (Fig. 4参照).ここで最も効率の良い流れ の形式は向流接触法 (カウンターカレント) であ る. そのため, 理想的な向流になるようにモジュー ル構造と流れの設計が行われる. Fig. 5 に水素分 離膜モジュールの概念を示す．シェル側に高圧の ガスを供給し, 透過速度の速い水素は膜を透過し, メタンや窒素など遅いガスはシェル側を通過して 非透過ガスとして集められる. 


\section{4. 工業的応用例}

\section{1 水素分離膜}

水素分離膜の用途は, プロセスガスからの水素 回収, 反応ガスの濃度調整，水素の高純度化が主 な用途である。産業利用例を Table 3 に示す。

石油は脱塩, 脱水されたのち, 原油精製装置に送 られ，ガス，ガソリン，灯油の各成分と残油に分 留される，液成分はさらに改質，分解，脱硫を経 てさらに精留されて製品となる．このとき多量の 水素を用いる場面があり, 各反応系の廃ガスから 膜を用いて水素を回収し，有効利用することが実 用化されている。

\subsection{1 石油精製オフガスの有効利用}

水素は石油精製工程で大量に使用されている。 従来精製末反応ガス（水素, 炭化水素) はオフガ

Table 3 Application of hydrogen separation membrane

\begin{tabular}{ll}
\hline 石油精製 & $\begin{array}{l}\text { 接触改質, 水素化分解, 水素化精製 } \\
\text { 水素化脱硫等の工程ガスからの水素回収 }\end{array}$ \\
化学工業 & 各種反応プロセスにおける $\mathrm{H}_{2}, \mathrm{CO}$ 比 \\
& 率調整 \\
& メタールプラントからの $\mathrm{H}_{2}$ 回収 \\
& アンモニアパージガスからの水素回収 \\
コークス炉ガスからの水素回収 \\
天然ガスからの He 回収 \\
高純度水素の製造 \\
\hline
\end{tabular}

スとして燃料に使用されてきた。しかし 50〜 $80 \%$ の水素を含むガスを有効利用すればさらに 利用価值が高まることになる．これまでに数多く の場面で水素の回収・有効利用が膜分離技術を用 いて行われてきた。 プラットフォーマーオフガス からの水素回収フローを Fig. 6 に, Table 4 に その運転の一例を示す．オフガス中にはガソリン 蒸気が同伴するが，フィードガスを昇温すること によりガソリン蒸気の凝縮を抑え，高い透過性を 維持している. 簡単な前処理だけで $73 \%$ の水素 を純度 98\%, 回収率 90\% 以上で分離回収してい る.

接触改質 $(\mathrm{CCR})$ における副生水素の回収利用 の例を Fig. 7, Table 5 に示す. 水素回収した残 りのガスは燃料ガス，あるいは夕ービン用ガスと して用いられる.

Table 4 Hydrogen recovery of platformer off gas

\begin{tabular}{ll|r|r|r}
\hline & フィード & 回 収 & 残ガス \\
\hline 流量 $\mathrm{Nm}^{3} / \mathrm{hr}$ & 7,340 & 4,940 & 2,400 \\
圧力 $\mathrm{kg} / \mathrm{cm}^{2} \mathrm{G}$ & 20 & 5 & 20 \\
温度 ${ }^{\circ} \mathrm{C}$ & 50 & - & - \\
組成 モル\% & & & \\
& & & \\
$\mathrm{H}_{2}$ & 73.1 & 98.6 & 20.4 \\
$\mathrm{C} 1$ & 10.0 & 1.1 & 28.4 \\
$\mathrm{C} 2$ & 7.9 & 0.3 & 23.6 \\
$\mathrm{C} 3 \sim$ & 9.0 & - & 27.6 \\
\hline
\end{tabular}

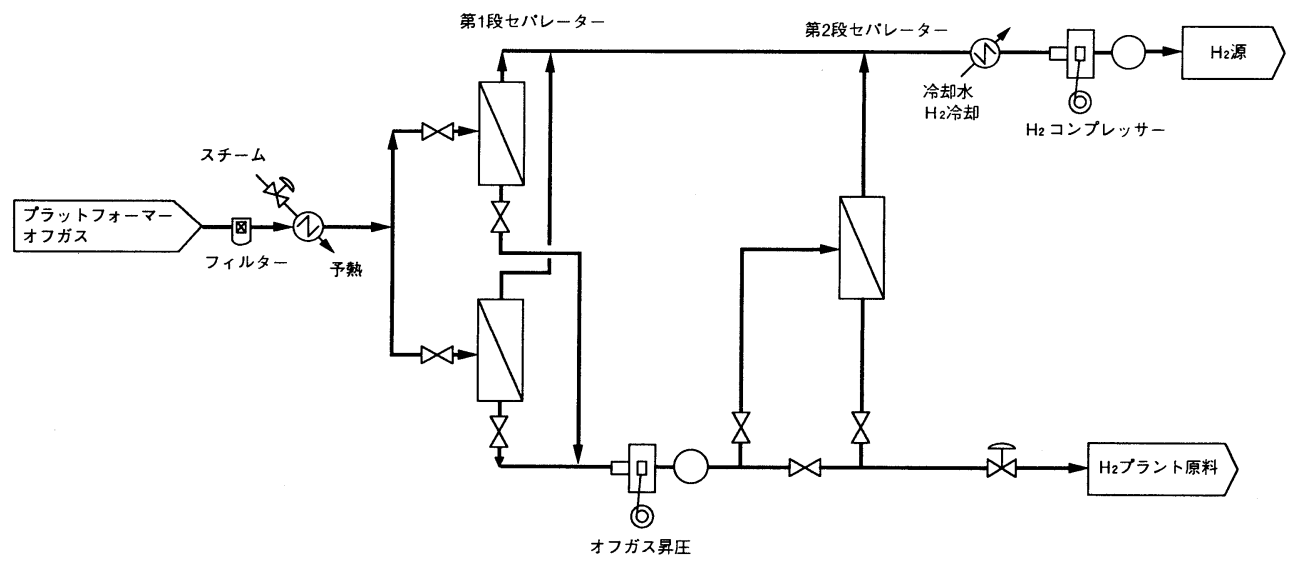

Fig. 6 Process flow diagram of hydrogen recovery of platformer off gas 
Table 5 Hydrogen recovery of CCR off gas

\begin{tabular}{l|r|r|r}
\hline & CCR オフガス & 生成ガス & ガスタービン \\
\hline 流量, $\mathrm{Nm}^{3} / \mathrm{hr}$ & 13,140 & 10,640 & 2,500 \\
圧力, $\mathrm{kg} / \mathrm{cm}^{2} \mathrm{G}$ & 25.0 & 10.0 & 24.0 \\
温度, ${ }^{\circ} \mathrm{C}$ & 40 & 90 & 90 \\
組成, $\mathrm{vol} \%$ & & & \\
$\mathrm{H}_{2}$ & 89.8 & 98.5 & 52.7 \\
$\mathrm{C} 1$ & 2.1 & 0.7 & 8.5 \\
$\mathrm{C} 2$ & 3.8 & 0.7 & 17.2 \\
$\mathrm{C} 3+$ & 4.3 & 0.1 & 21.6 \\
\hline
\end{tabular}

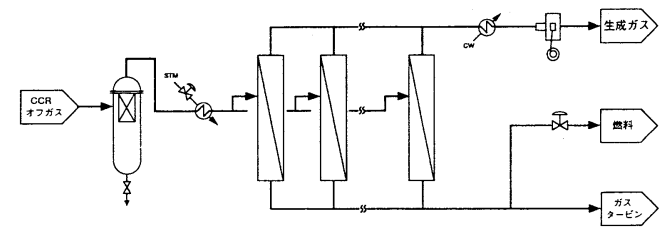

Fig. 7 Process flow diagram of hydrogen recovery of CCR off gas

Table $6 \mathrm{H}_{2} / \mathrm{CO}$ ratio adjustment, $\mathrm{H}_{2}$ reparation and $\mathrm{CO}$ enrichment of synthesis gases

\begin{tabular}{l|c|c|c|c}
\hline 番号 & (1) & \multicolumn{1}{c}{$(2)$} & (3) & \multicolumn{1}{c}{ (4) } \\
\hline ガス流量, $\mathrm{Nm}^{3} / \mathrm{hr}$ & 10,000 & 3,356 & 6,614 & 915 \\
\hline ガス圧力, $\mathrm{kg} / \mathrm{cm}^{2} \mathrm{G}$ & 43.0 & 9.0 & 43.0 & - \\
\hline ガス温度, ${ }^{\circ} \mathrm{C}$ & \multicolumn{1}{c|}{50} & \multicolumn{1}{c}{45} & \multicolumn{1}{c}{50} & \multicolumn{1}{c}{45} \\
\hline 組成, vol\% & & & & \\
$\mathrm{H}_{2}$ & 66 & 99.25 & 49.20 & 66.00 \\
$\mathrm{CO}$ & 33 & 0.62 & 49.36 & 32.97 \\
$\mathrm{CO}_{2}$ & 0.2 & 0.13 & 0.24 & 0.63 \\
$\mathrm{CH}_{4}$ & 0.8 & 0.00 & 0.12 & 0.40 \\
\hline
\end{tabular}

化学工業における水素分離膜利用場面として は, 反応系から排出されるガスからの水素回収や オキソ合成用ガスの濃度調整が主である. Fig.

8, Table 6 にポリイミド膜を用いたオキソ合成 用ガスの製造フローの例を示す。 システムリ フォーマーから得られたガスを, 膜を用いて $\mathrm{H}_{2} / \mathrm{CO}$ が $1 / 1$ の組成比のガスに比率調整し, 残 りの水素リッチなガスは水素原料として用い, 他 は供給ガスへとリサイクルしている. オキソ合成

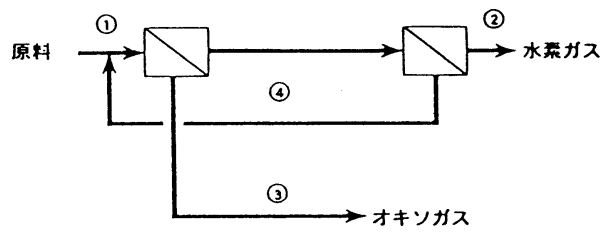

Fig. $8 \mathrm{H}_{2} / \mathrm{CO}$ ratio adjustment, $\mathrm{H}_{2}$ separation and $\mathrm{CO}$ enrichment of synthesis gases

用ガスは膜の非透過側のガスであり供給圧力がほ ぼ維持されているため再昇圧のエネルギーが少な くてすみ, 高圧ガスを取り扱うプロセスにおいて は有利である.

\section{2 炭酸ガス分離膜}

主な用途は, 天然ガス, バイオガス中の炭化水 素と炭酸ガスの分離・カロリーアップ, 石油三次 回収 (EOR) における炭酸ガスの分離・回収であ る. 分離対象は $\mathrm{CO}_{2} / \mathrm{CH}_{4}$ が中心である. 炭酸 ガスは高分子膜に対する溶解度が大きく, 高圧使 用の場合には可塑化作用のため分離係数が低下す る場合がある. 長期使用に耐える耐久性に優れた 膜の選定が重要であり, ポリイミドはその有力な 候補である。

\section{2.1 天然ガスの脱炭酸}

天然ガスは圧力 $60 \sim 120 \mathrm{kgf} / \mathrm{cm}^{2}$, メタンを主 成分とする炭化水素で, 不純物として炭酸ガスの 他に窒素, 水分, 微量の硫黄成分が含まれている. 炭化水素が $98 \%$ 以上であれば水分を除去してそ 
Table 7 Field test module and test condition for natural gas treatment

\begin{tabular}{|c|c|c|}
\hline & $\begin{array}{l}\text { Cellulose Acetate } \\
\text { Membrane }\end{array}$ & $\begin{array}{l}\text { Polyimide } \\
\text { Membrane }\end{array}$ \\
\hline Module & spiral-wound & hollow fiber \\
\hline Inlet Volume $\mathrm{MNm}^{3} \mathrm{~d}$ & $50(1.87 \mathrm{MMscfd})$ & 50 (1.87 MMscfd) \\
\hline Inlet Pressure bar & 65 (940 psig) & 65 (940 psig) \\
\hline Inlet Temperature ${ }^{\circ} \mathrm{C}$ & $43(109 \operatorname{deg} F)$ & $70(158 \operatorname{deg} \mathrm{F})$ \\
\hline $\mathrm{CO}_{2} \%$ in Non-Permeate $\%$ & 2 & 2 \\
\hline Permeate Volume $\mathrm{MNm}^{3} \mathrm{~d}$ & 11 (409 Mscfd) & 10.5 (392 Mscfd) \\
\hline Permeate Pressure bar & 4.9 (71 psig) & 4.9 (71 psig) \\
\hline $\begin{aligned} \text { Feed Gas Component } ; & \mathrm{C} 1 \\
& \mathrm{C} 2 \sim \\
& \mathrm{CO}_{2} \\
& \text { Other }\end{aligned}$ & $\begin{array}{r}83.89 \\
7.76 \\
6.08 \\
2.18\end{array}$ & \\
\hline
\end{tabular}

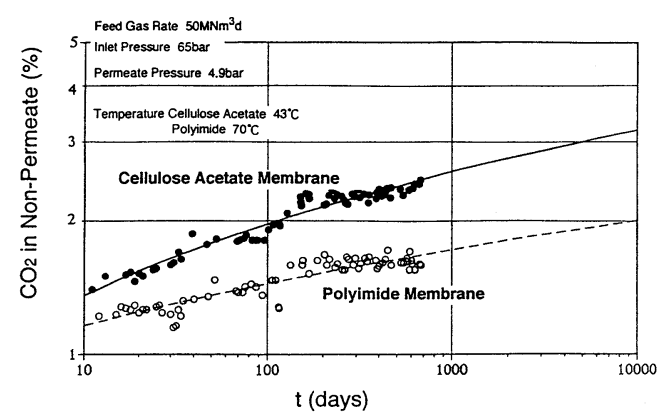

Fig. $9 \mathrm{CO}_{2}$ in Non-Permeate Versus Time

のままパイプラインで移送可能である. しかし $\mathrm{CO}_{2}$ が許容量以上に含まれる場合, $\mathrm{CO}_{2}$ は発熱 量低下をもたらす上に, パイプラインの腐食の原 因となる。 $\mathrm{CO}_{2}$ の除去には吸収法が知られてい るが, 膜の性能の向上と共に運転コスト, 設備コ スト,メンテナンスの上から膜法の優位性が認め られつつある.

Iwakami ら ${ }^{4)}$ は天然ガスの脱炭酸ガスを酢酸 セルロース膜およびポリイミド膜を用いてテスト した. Table 7 に操作条件を示す. $6 \%$ の炭酸ガ スを $2 \%$ 以下に脱炭酸する条件を設定して行われ た結果, 酢酸セルロース膜が 100 日程度で条件を 達成できなくなったのに対し，ポリイミド膜につ いては 2 年経過後においても $1.7 \%$ 以下に保つこ とができ，分離性，耐久性いずれも充分であった (Fig. 9).
Table 8 Landfill gas treatment

\begin{tabular}{lrcc}
\hline & 原料 & セールスガス & オフガス \\
\hline 流量, $\mathrm{Nm}^{3} / \mathrm{hr}$ & 350 & 217 & 133 \\
圧力, $\mathrm{kg} / \mathrm{cm}^{2} \mathrm{G}$ & 0 & 32 & 0.2 \\
温度, ${ }^{\circ} \mathrm{C}$ & 30 & 60 & 50 \\
組成, $\mathrm{vol} \%$ & & & \\
$\quad \mathrm{CO}_{2}$ & 39 & 10.6 & 85.3 \\
$\mathrm{CH}_{4}$ & 60 & 88 & 14.3 \\
$\mathrm{~N}_{2}$ & 0.9 & 1.3 & 0.3 \\
$\mathrm{O}_{2}$ & 0.1 & 0.1 & 0.1 \\
$\mathrm{H}_{2} \mathrm{O}$ & 飽和 & & \\
\hline
\end{tabular}

\section{2.2 ランドフィルガスの脱炭酸}

生活系廃棄物等の有機物を地中に埋立すると廃 棄物は微生物によりメタンと炭酸ガスに分解され る. 発生するガスの成分は廃棄物成分の種類によ るが, およそ $\mathrm{CO}_{2} 40 \%, \mathrm{CH}_{4} 50 \%, \mathrm{~N}_{2}$ 水蒸気, その他の微量ガス成分からなる ${ }^{5)}$.このガスから 不純物である $\mathrm{CO}_{2}$ その他を除去すれば良質の燃 料ガスが得られる. 利用可能な埋め立て地のガス 発生量は数百〜数千 $\mathrm{Nm}^{3} / \mathrm{hr}$ にすぎないが，そ の数は非常に多く, 北米では数千箇所におよぶと 言われている. 北米やヨーロッパでは，ガス分離 膜によるランドフィルガスの脱炭酸ガスプロセス が実用段階に入っている. ポリイミド膜を用いた ランドフィルガスからの脱炭酸ガスの実例を Fig. 10, Table 8 に示す. 炭酸ガス濃度を下げる 目的で二段処理を行っている例もある. 


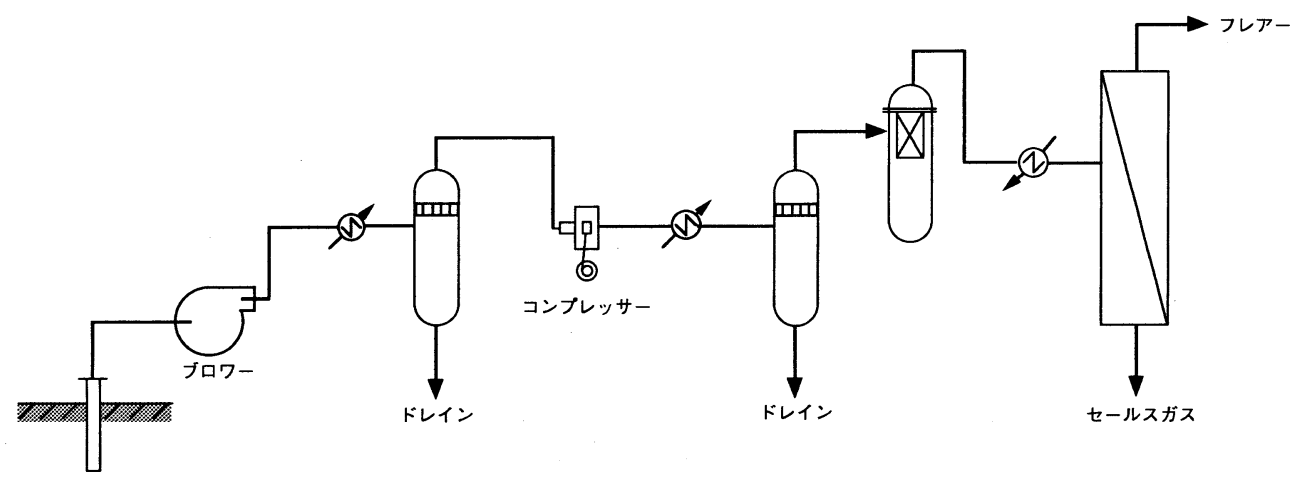

Fig. 10 Process flow diagram of landfill gas treatment

\section{5. おわりに}

最近, 環境問題が盛んに議論され, 地球温暖化 防止の方法論が数多く提案されている. 重要なこ との 1 つに, 資源の有効利用と省エネルギーが挙 げられる. 水素分離, 炭酸ガス分離の用例に見ら れるように, 膜は資源の有効利用, 省エネルギー の点からまさに打ってつけのプロセスと見なせ る. 今後このプロセスが幅広く採用され, 環境改 善の一助となることを期待している.

\section{文献}

1) Y. Hirayama, T. Yoshinaga, Y. Kusuki, K. Ninomiya, T. Sakakibara, T. Tamari, J.Membrane Sci., 111, 169, 183 (1996)

2) R. E. Kesting, A. K. Fritzsche, Polymericgas separation membranes p320 (1993) John wiley \& sons, INC.

3）吉永利宗, 楠木喜博, 成形加工, 5 (10), 683, (1993)

4) Y. Iwakami, Abstracts of the 1993 ICOM

5）例えば, R. Rautenbach, K. Welsch, Desalination, 90, 193 (1993)

（受付日 1996 年 6 月 11 日 掲載決定 7 月 2 日） 